Science and Football

Pensar en Movimiento:

Revista de Ciencias del Ejercicio y la Salud

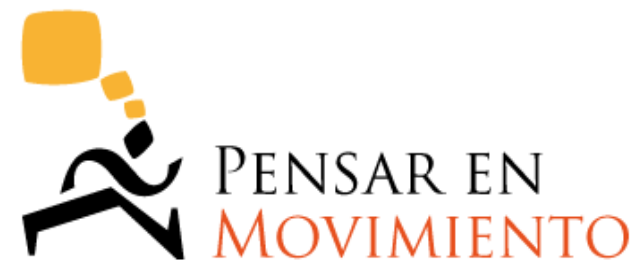

ISSN 1659-4436

Vol. 15, No.1, pp. 1- 11

Closing on June 30,2017

\title{
KINEMATIC DEMANDS OF TWO SMALL-SIDED GAMES OF COSTA RICAN COLLEGE SOCCER PLAYERS ${ }^{1}$
}

\author{
Daniel Rojas-Valverde, M.Sc. ${ }^{2,3}(A, B, C, D, E) ;$ María Morera-Castro, Ph.D. ${ }^{3(C, D, E)}$; Jaqueline \\ Montoya-Rodríguez ${ }^{2,3(B, C, D, E)}$; and Randall Gutiérrez-Vargas, M.Sc. ${ }^{2,3(A, B, C, D, E)}$ \\ daniel.rojas.valverde@una.cr \\ ${ }^{2}$ Center for Research and Diagnosis in Health and Sports, Universidad Nacional, \\ Costa Rica \\ ${ }^{3}$ School of Human Movement Sciences and Quality of Life, \\ Universidad Nacional, Costa Rica
}

Original submission: 08/10/2016; resubmitted: 11/16/2016, 03/03/217, 05/26/2017; accepted: 05/26/2017; published: 06/16/2017.

Doi: http://dx.doi.org/10.15517/pensarmov.v15i1.25902

\begin{abstract}
Rojas-Valverde, D., Morera-Castro, M., Montoya-Rodríguez, J., \& Gutiérrez-Vargas, R. (2017). Kinematic demands of two small-sided games of Costa Rican college soccer players. Pensar en Movimiento: Revista de Ciencias del Ejercicio y la Salud, 15(1), 111. The purpose of this paper was to compare two small-sided games kinematics of Costa Rican college soccer players. Two SSG (2x10min, 3 min rest in between), C1 $\left(600 \mathrm{~m}^{2}\right)$ and C2 $\left(1200 \mathrm{~m}^{2}\right)$, were played by 14 college soccer players of Costa Rica. Global Positioning System was used to measure kinematic and physiological variables in both conditions. A mixed ANOVA was used, results suggested $\mathrm{C} 1$ and $\mathrm{C} 2$ were statistically different in speed $(\mathrm{C} 1<\mathrm{C} 2)$, distance $(\mathrm{C} 1<\mathrm{C} 2)$ and heart rate $(\mathrm{C} 1>\mathrm{C} 2)$. When analyzing the distance covered by speed category (low, moderate and high running actions) results suggest C2 had higher intensities compared to $\mathrm{C} 1$. This research confirms the findings of previous
\end{abstract}

${ }^{1}$ Original submission in English. Also available in the Spanish-translated version in this journal.

-1 -

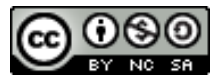


studies on the effectiveness of SSG to simulate real game conditions in short periods of time. Conclusions: $\mathrm{C} 2$ had higher intensities compared to $\mathrm{C} 1$ game with lower physiological demand. Likewise, the $\mathrm{C} 2$ resembles more accurately matches in official conditions of Costa Rican players.

Keywords: Global Positioning Systems (GPS); youth; sports; speed; distance.

\section{RESUMO}

Rojas-Valverde, D., Morera-Castro, M., Montoya-Rodríguez, J., \& Gutiérrez-Vargas, R. (2017). Kinematic college soccer players. PensAR en Movimiento: Revista de Ciencias del Ejercicio y la Salud, 15(1), 1-11. O propósito desta pesquisa foi comparar as demandas cinemáticas em dois tipos de dimensões de jogo em 14 jogadores costarricenses de futebol universitário. Estes jogaram dois jogos em campo reduzido (SSG) (2x10 min, 3 min de descanso): C1 $\left(600 \mathrm{~m}^{2}\right)$ e C2 (1200 $\left.\mathrm{m}^{2}\right)$. Utilizou-se um Sistema de Posicionamento Global para medir as variáveis cinemáticas e fisiológicas em ambas as condições. Utilizou-se um ANOVA misto; os resultados sugeriram que C1 e C2 foram estatisticamente diferentes em velocidade $(\mathrm{C} 1<\mathrm{C} 2)$, distância $(\mathrm{C} 1<\mathrm{C} 2)$ e frequência cardíaca $(\mathrm{C} 1>\mathrm{C} 2)$. Ao analisar a distância percorrida pela categoria de velocidade, em ações de corrida baixa, moderada e alta intensidade, os resultados sugerem que C2 possui maiores intensidades em comparação a $\mathrm{C} 1$. Esta pesquisa confirma os resultados de estudos prévios sobre a efetividade de SSG para simular condições de jogo real em períodos curtos de tempo. Conclusões: O C2 apresentou uma maior intensidade em comparação ao jogo $\mathrm{C} 1$, com menores demandas fisiológicas. Igualmente, o C2 reflete de maneira mais exata as condições em jogos oficiais de jogadores costarricenses.

Palavras chave: Sistemas de Posicionamento Global (GPS); jovens; esportes; velocidade; distância.

Soccer is probably the most popular sport in the world, with millions of active players globally. As explained by Jones and Drust (2007), soccer performance is a result of the player's physiological capabilities, psychological and social factors, and technical and tactical skills. Today, this game demands high intensity, in order to execute a dynamic and fast performance (Safania, Alizadeh \& Nourshahi, 2011). The demands required in this sport, where high intensity efforts are interspersed with periods of low intensity load (Romero \& Fernández, 2014), require professional field staff to improve their methodologies during training, with the aim of achieving physiological adaptations and performance required by changes in the gameplay dynamics.

Due to the great influence of this discipline, technology has become an essential tool for improving the quality and efficiency of the game. Recent advances to technology resources allow maintaining best controls on training, and get more rigorous and accurate planning and prescription of training loads (Barbero, Vera, \& Castagna, 2006; Casamichana \& Castellano, 2010). 
Currently, technology such as heart rate monitors, lactate analyzers, Global Positioning System (GPS), respiratory rate monitors, remote monitoring thermometers, video analysis, among other devices, have facilitated measurements, assessments and monitoring of physiological demands in sports like soccer (Barbero, Barbero, Gómez \& Castagna, 2009; Casamichana \& Castellano, 2010; Hill-Haas, Dawson, Impellizzeri \& Coutts, 2011). These devices allow better control of the training and performance of the players, whether during practice or in official games.

Daneshjoo, Halim, Rahnama and Yusof (2013) and Stolen, Chamari, Castagna and Wisloff (2005) mention that these technological advances allow detecting changes such as variation in game intensity more accurately; in soccer, various intermittent actions of high intensity and short duration and aerobic base exercises are combined, causing an impact on the morphological and mechanical lower limb muscles characteristics, such as increased stiffness and muscle tone (Kubo, Kanehisa, Ito \& Fukunaga, 2001).

In this sport, the small sided games (SSG) are used as a method to achieve high intensities simulating an official game's characteristics (Aguilar, Botelho, Lago, Macas, \& Sampaio, 2012; Casamichana, Castellano, González, García \& García, 2011; Katis \& Kellis, 2009; Safania et al., 2011). This training activity is an adaptation of the real game situation applied in practice, varying the dimensions of the playing field, reducing the number of players participating and modifying official rules, such as the participation of the goalkeeper and duration of physical work (Casamichana \& Castellano, 2010; Casamichana \& Castellano, 2011; Dellal et al., 2012; Hill-Haas et al., 2011; Jones \& Drust, 2007; Katis \& Kellis, 2009; Safania et al., 2011). SSG are a simpler but highly effective and efficient method; the results of studies suggest that this methodology increases the player's physiological capabilities significantly. Mainly, it seeks to translate the complexity of the game situation at training sessions, through a holistic improvement, where beyond the physical and technical and tactical advances, you must use a fast and efficient decision-making (Dellal et al., 2012).

The use of GPS has been incorporated to control training sessions to quantify the physical and physiological loads that a physical exercise causes, through variables such as heart rate, average speed, impacts and total distance covered by a player, allowing daily, weekly or even full-season volume quantification, for groups and individuals, in real time (Gómez, Pallarés, Díaz, \& Bradley, 2013).

Due to the necessity for soccer trainers and coaches to control the intensity of training and competition, it is essential to conduct studies focused on determinate the intensity variations depending on pitch dimensions. The purpose of this study was to compare two small-sided games kinematics of Costa Rican college soccer players.

\section{METHODOS}

Participants. A total of 14 male players (age $20.9 \pm 1.92$ years, weight $69.6 \pm 7.3$ $\mathrm{kg}$, height $172 \mathrm{~cm} \pm 6.3$ ) participated. These players were training three to four times per 
week and were competing regularly, at least once a week belonging to a college soccer team of Costa Rica, who were in preparation for the 2015 inter-university knockout phase.

All subjects were informed of the details of the experimental procedures and the associated risks and discomforts. Each subject gave written informed consent according to the criteria of the Declaration of Helsinki regarding biomedical research involving human subjects (18th Medical Assembly, 1964; revised 2013 in Fortaleza).

Instruments. Body weight measurement was performed using a digital scale (sensitivity $\pm 0.1 \mathrm{~kg}$ ) (Elite Series BC554, Tanita-Ironman, Illinois, United States) and to know the height of the players a wall stadiometer was used.

To measure kinematic variables, as speed and distance, a Global Positioning System (GPS) (SP PRO X II GPSports ${ }^{\circledR}, 15 \mathrm{~Hz}$, Canberra, Australia) was used. The validity and reliability of $15 \mathrm{~Hz}$ GPS devices have been demonstrated by Barbero et al. (2009). According to the authors this equipment has a high speed and sprint tests correlation values $\left(r^{2}=.87, p<.001 ; r^{2}=.94, p<.001\right)$. Likewise, the cumulative maximum speed and the maximum speed reached recorded a low coefficient of variation ( $C V=1.7 \%$ and $1.2 \%$ respectively). In turn, Johnston, Watsford, Kelly, Pine and Spurrs (2014) report acceptable reliability through a temporary test (test, re-test, $r=.75$ ). This instrument was used to quantify the variables: average of distance in meter covered per $\mathrm{min}(\mathrm{m} / \mathrm{min})$, average heart rate (beats $/ \mathrm{min})$ and average speed $(\mathrm{km} / \mathrm{h})$. Team $A M S \circledast$, V2.5.4 (GPSports, Camberra, Australia) software was used for information analysis.

To perform the analysis of the information collected by GPS, the distance covered (m) was categorized by intensity of motion according to Di Salvo et al. (2007) in: standingjogging $(0-11 \mathrm{~km} / \mathrm{h}), \%$ low intensity running $(11.1-14 \mathrm{~km} / \mathrm{h}), \%$ moderate intensity running (14.1-19 km/h) and \% high intensity running (19.1-23 km/h).

Procedures. An information session with participants and informed consent sign was made. Weight and height were measured for each participant.

Two different SSG conditions were measured on consecutive days, 24 hours apart, and were performed before normal training (7:00 a.m.) and with activation/warm up 10 minutes prior to $\mathrm{C} 1$ and $\mathrm{C} 2$. Condition 1 (C1) had dimensions of $20 \times 30$ meters $\left(600 \mathrm{~m}^{2}\right.$ total pitch area $-42.86 \mathrm{~m}^{2}$ area per player [APP]) and condition 2 (C2) had 30x40 meters $\left(1200 \mathrm{~m}^{2}\right.$ total pitch area $-85.1 \mathrm{~m}^{2}$ APP). Both sessions were held on the same pitch (natural turf), with the same players (7 vs. 7 , two teams randomly selected and maintained in both conditions), same balls and same total playing time (2x10 min, with 3 minutes' rest and hydration). Goal lines were 3 meters wide, there weren't goalkeepers, and there were two balls on each side of the field to maintain the dynamic of the game reducing breaks. The players were asked not to perform strenuous exercise at least 24 hours prior to performing both conditions.

Statistical analysis. Results are expressed as means \pm standard deviation $(S D)$. Data were tested for normal distribution using the Shapiro-Wilk test. Data of heart rate, 
distance, speed and \% distance covered at standing-jogging, low, moderate and high running intensities were subjected to a 2 (condition) $\times 2$ (period) mixed model ANOVA with an alpha set prior at $p<.05$. The magnitudes of the differences for all variables were analysed using the omega partial squared $\left(\omega_{p}^{2}\right)$ for ANOVA analysis and qualitatively categorized as follow $\omega_{p}^{2}=.15$ high effect, $\omega_{p}^{2}=.06$ moderate effect and $\omega_{p}^{2}=.01$ as small effect (Cohen, 1977). This analysis was implemented because $\omega_{p}^{2}$ is not affected by small size samples (Moncada, Solera \& Salazar, 2002). The data analysis was performed using Statistical Package for the Social Sciences (SPSS, IBM, SPSS Statistics, V 22.0 Chicago, IL, USA).

\section{RESULTS}

Descriptive statistics of the variables by period and condition are shown in Table 1 and 2.

Table 1

Descriptive statistics of the variables distance, speed and heart rate by period and condition

\begin{tabular}{cccc}
\hline Variable & Period & $\mathbf{C 1}\left(\mathbf{6 0 0} \mathbf{~ m}^{2}\right)$ & $\mathbf{C 2}\left(\mathbf{1 2 0 0} \mathbf{~ m}^{\mathbf{2}}\right)$ \\
\hline \multirow{2}{*}{ Distance $(\mathrm{m} / \mathrm{min})$} & First & $107.4 \pm 8.3$ & $115.7 \pm 7.4$ \\
& Second & $105.9 \pm 9$ & $116.3 \pm 10.5$ \\
\hline \multirow{2}{*}{ Speed $(\mathrm{km} / \mathrm{h})$} & First & $6.4 \pm .5$ & $6.9 \pm .4$ \\
& Second & $6.4 \pm .5$ & $7 \pm .6$ \\
\hline \multirow{2}{*}{ Heart rate $(\mathrm{bpm})$} & First & $163.3 \pm 9.2$ & $152.1 \pm 11.3$ \\
& Second & $166 \pm 10.2$ & $155.1 \pm 18.6$ \\
\hline
\end{tabular}

Source: the Authors.

Table 2

Descriptive statistics of the distance covered $(m)$ by intensity in period and condition

\begin{tabular}{cccc}
\hline Variable & Period & $\mathbf{C 1}\left(\mathbf{6 0 0} \mathbf{~ m}^{\mathbf{2}}\right)$ & $\mathbf{C 2}\left(\mathbf{1 2 0 0} \mathbf{~ m}^{\mathbf{2}}\right)$ \\
\hline \multirow{2}{*}{ Standing-Jogging $(\mathrm{m})$} & First & $848 \pm 47.5$ & $816.2 \pm 65.3$ \\
& Second & $826.5 \pm 56.5$ & $819 \pm 64.68$ \\
\hline \multirow{2}{*}{ Low intensity $(\mathrm{m})$} & First & $152.1 \pm 38.5$ & $198 \pm 24.6$ \\
& Second & $145.6 \pm 32.9$ & $193.6 \pm 50.1$ \\
\hline \multirow{2}{*}{ Moderate intensity $(\mathrm{m})$} & First & $70.4 \pm 28.7$ & $121.9 \pm 42.4$ \\
& Second & $75.6 \pm 14.6$ & $121.4 \pm 50.2$ \\
\hline \multirow{2}{*}{ High intensity $(\mathrm{m})$} & First & $3.9 \pm 5$ & $17.9 \pm 14.4$ \\
& Second & $9.7 \pm 9.2$ & $23.9 \pm 25.9$ \\
\hline
\end{tabular}

Source: the Authors. 
The 2x2 mixed model ANOVA showed no statistically significant interaction (condition vs. period) in distance, $F_{(1,13)}=.366, p=.551, \omega_{p}^{2}=0$ (low). Nevertheless, there was a significant main effect of condition $F_{(1,13)}=11.833, p=.002, \omega_{p}^{2}=0.27$ (high), with C2 being higher than $\mathrm{C} 1$ in distance. There were not significant differences in main analysis by period $F_{(1,13)}=.068, p=.796, \omega_{\mathrm{p}}^{2}=0$ (low).

The ANOVA showed no statistically significant interaction (condition vs. period) in speed, $F_{(1,13)}=.380, p=.543, \omega_{p}^{2}=0$ (low). Nevertheless, there was a significant main effect of condition $F_{(1,13)}=11.833, p=.002, \omega_{p}^{2}=0.27$ (high), with $\mathrm{C} 2$ being higher than $\mathrm{C} 1$ in speed. There was no significant difference in main analysis by period $F_{(1,13)}=.026, p=$ $.872, \omega_{p}^{2}=0$ (low).

Results showed no statistically significant interaction (condition vs. period) in heart rate, $F_{(1,13)}=.009, p=.924, \omega_{p}^{2}=0$ (low). Nevertheless, there was a significant main effect of condition $F_{(1,13)}=6.048, p=.021, \omega_{p}^{2}=.15$ (high), with a higher heart rate for C1 than C2. There was no significant difference in main analysis by period $F_{(1,13)}=2.418 p=.132, \omega_{p}^{2}=$ .04 (low).

The 2x2 mixed model ANOVA for distance covered based in intensity showed no statistically interaction in standing-jogging, $F_{(1,26)}=.313, p=.581, \omega_{p}^{2}=0$ (low); low intensity, $F_{(1,26)}=.015, p=.904, \omega_{p}^{2}=0$ (low); moderate intensity, $F_{(1,26)}=.537, p=.470$, $\omega_{p}^{2}=0$ (low); and high intensity, $F_{(1,26)}=.052, p=.822, \omega_{p}^{2}=0$ (low). The main effects analysis by condition of this kinematic variables indicated that there were significant differences in: standing-jogging, $F_{(1,26)}=23.639, p=.000, \omega_{p}^{2}=.45$ (high); low intensity, $F_{(1,26)}=7.009, p=.014, \omega_{p}^{2}=.18$ (high); moderate intensity, $F_{(1,26)}=15.82, p=.000, \omega_{p}^{2}=.35$ (high); and in high intensity, $F_{(1,26)}=13.871, p=.001, \omega_{p}^{2}=.31$ (high). The main effects analysis by period of the distance covered based in intensity indicated there were no significant differences in: standing-jogging, $F_{(1,26)}=1.469, p=.236, \omega_{p}^{2}=.02$ (low); low intensity, $F_{(1,26)}=.387, p=.539, \omega_{p}^{2}=0$ (low); moderate intensity, $F_{(1,26)}=.09, p=.766, \omega_{p}^{2}=$ 0 (low); and in high intensity, $F_{(1,26)}=2.888, p=.101, \omega_{p}^{2}=.06$ (moderate).

\section{DISCUSSION}

It is known that, at present, training methodologies have favored high-intensity work in conditions as close as possible to the competition. Small-sided games have come to meet these intensity requirements (Romero \& Fernández, 2014). Because there are multiple interactions, the analysis is made based on the space in square meters each player has to run the game (Febré et al., 2015).

Age, height and weight of the participants in this study are similar to others, e.g.: Castellano, Fernández, Castillo, and Casamichana (2010), with a sample of university young players $(20.1 \pm 1.2$ years, height $176.3 \pm 9.9 \mathrm{~cm}$; weight $63.5 \pm 8.4 \mathrm{~kg})$ and Vargas, Urkiza, and Gil (2015), who studied the behavior of different variables in players with similar anthropometric data $(20.9 \pm 1.7$ years; $1.80 \pm 0.05 \mathrm{~cm} ; 73.1 \pm 5.3 \mathrm{~kg})$ during the performance of SSG in training and matches. 
The results of this study showed that an increase of pitch dimensions leads to more demanding physical conditions, for example by comparing $\mathrm{C} 1$ with $\mathrm{C} 2$, the latter has significantly greater differences than $\mathrm{C} 1$ in first and second period's distance covered. The results of meters covered per minute in $\mathrm{C} 1$ and $\mathrm{C} 2$ are similar to those obtained by other studies of SSG under similar conditions to the current study (Casamichana, San RamónQuintana, Castellano, \& Calleja-González, 2012; Casamichana \& Castellano, 2010; Casamichana, Castellano, \& Hernández-Mendo, 2014; Hill-Haas, Rowsell, Dawson, \& Coutts, 2009; Rampinini et al., 2007).

As for mean speed, there were significant differences between $\mathrm{C} 1$ and $\mathrm{C} 2$, in the first period and second period, being $\mathrm{C} 2$ significantly greater than $\mathrm{C} 1$. Previous studies mention that as they increase the dimensions of the pitch, the kinematic requirements (average speed and distance) increase proportionally (Casamichana, Castellano, \& Castagna, 2012; Dellal et al., 2012; Nevado-Garrosa \& Suárez-Arrones, 2015; Rampinini et al., 2007).

Results of this study suggest differences significantly higher in speed categories by condition, $\mathrm{C} 2$ being higher in all categories except in standing-jogging. This means that there were higher intensity actions in $\mathrm{C} 2$. This is clear when observing the significant differences between $\mathrm{C} 1$ conditions and $\mathrm{C} 2$ not only in low intensity categories but in those that require high intensity and sprints, similar to previously reported by Nevado-Garrosa and Suárez-Arrones (2015), Casamichana, San Ramón-Quintana, Calleja-Gonzalez, and Castellano (2013) and Dellal et al. (2012).

Analyzing the effectiveness of SSG to simulate real game conditions on Costa Ricans soccer players, it is stated that both the $\mathrm{C} 1$ and $\mathrm{C} 2$ simulate the kinematics and heart rate demands of official matches reported prior in a study with a sample of Brazilian players (Barros et al., 2007) and Costa Rican players (Gutiérrez-Vargas et al., 2015), and analyses of the players from the South Africa World Cup in 2010 (Clemente, Santos, Lourenco, Ognyanova \& Mendes, 2013). Thus, the percentage distribution of distance covered by speed-intensity was similar to these prior studies made in 11 vs. 11 conditions (Barros et al., 2007; Gutiérrez-Vargas et al., 2015), which indicate that the higher percentage distance in official pitch dimension is executed at standing-jogging speed.

As for the physiological data, significantly higher differences in C1 compared to C2 were obtained, similar to those reported by Casamichana, et al. (2014) and Casamichana et al. (2011). These results are in disagreement with those mentioned by Kelly and Drust (2009) who indicated that heart rate did not vary significantly when running SSG in different pitch dimensions $\left(600 \mathrm{~m}^{2}, 1200 \mathrm{~m}^{2}\right.$ and $\left.2500 \mathrm{~m}^{2}\right)$. According to Allen, Butterfley, Welsh, and Wood (1998), mean heart rate in a smaller pitch is higher because there is greater participation of players in the activity compared with larger pitch dimensions. Febré et al. (2015) noted that heart rate was significantly lower when playing in a smaller APP $\left(90 \mathrm{~m}^{2}\right)$ than when playing in a larger one $\left(150 \mathrm{~m}^{2}\right.$ per player), contrary to the present study, where the smaller APP $\left(42.86 \mathrm{~m}^{2}\right)$ resulted in a higher average heart rate than the larger $\operatorname{APP}\left(85.71 \mathrm{~m}^{2}\right)$. 
These results, related to kinematic variables behavior in SSG, are relevant because of the extended use of this kind of training methods for soccer teams in Costa Rica and worldwide, providing more information to coaches and staff of what kind of variables they got to change to obtain higher or lower responses in speed, distance or heart rate.

This study confirms the findings of previous studies on the effectiveness of SSG to simulate real game conditions in short periods of time. The results indicated $\mathrm{C} 2$ had higher intensities compared to C1 game with lower physiological demand. Likewise, the C2 resembles more accurately matches in official conditions of Costa Rican players.

\section{REFERENCES}

Aguilar, M., Botelho, G., Lago, C., Macas, V., \& Sampaio, J. (2012). A review on the effects of soccer small-sided games. Journal of Human Kinetics, 33, 103-113. Retrieved from http://www.johk.pl/volume 33.html

Allen, J.D., Butterfly, R., Welsh, M.A., \& Wood, R. (1998). The physical and physio-logical value of 5 -a-side soccer training to 11 -a-side match play. Journal of Human Movement Studies, 34(1), 1-19. Retrieved from https://www.researchgate.net/publication/ 224767111 The Physical and Physiological Value of 5-A-Side Soccer Training to 11-A-Side Match Play

Barbero, J., Vera, J., \& Castagna, C. (2006). Cuantificación de la carga de fútbol: Análisis de un juego en Espacio Reducido. Journal PubliCE Premium. Retrieved from http://g-se.com/es/evaluacion-deportiva/articulos/cuantificacion-de-la-carga-enfutbol-analisis-de-un-juego-en-espacio-reducido-783

Barbero, J., Barbero, V., Gómez, M., \& Castagna, C. (2009). Análisis cinemático del perfil de actividad en jugadoras infantiles de fútbol mediante tecnología GPS. Kronos Rendimiento en el deporte, 18(14), 35-42. Retrieved from http://abacus.universidadeuropea.es/handle/11268/3257

Barros, R., Misuta, M., Menezes, R., Figueroa, P., Moura, F., Cunha, S., Anido, R., \& Leite, R. (2007). Analysis of distance covered by first division Brazilian soccer players obtained with an automatic tracking method. Journal of Sport Science and Medicine, 6, 233-242. $\quad$ Retrieved from http://www.jssm.org/abstresearcha.php?id=issm-06-233.xml

Casamichana, D. \& Castellano, J. (2010). Time-motion, heart rate, perceptual and motor behavior demands in small-sides soccer games: Effects of pitch size. Journal of Sports Sciences, 28(14), 1615-1623. doi: https://doi.org/10.1080/ $\underline{02640414.2010 .521168}$

Casamichana, D., Castellano, J., González, A., García. H., \& García., J. (2011). Demanda fisiológica en juegos reducidos de fútbol con diferente orientación del espacio. 
International Journal of Sport Science, 23(7), 141-154. Retrieved from http://www.cafyd.com/REVISTA/02306.pdf

Casamichana, D. \& Castellano, J. (2011). Demandas físicas en jugadores semiprofesionales de fútbol: ¿Se entrena igual que se compite? Revista Cultura Ciencia Deporte, 6(17), 121-127. Retrieved from http://www.redalyc.org.una. idm.oclc.org/articulo.oa?id=163022532006.

Casamichana, D., Castellano, J., \& Castagna, C. (2012). Comparing the Physical Demands of Friendly Matches and Small-Sided Games in Semiprofessional Soccer Players. Journal of Strength and Conditioning Research, 26(3), 837-843. doi: https://doi.org/10.1519/JSC.0b013e31822a61cf

Casamichana, D., Castellano, J., \& Hernández-Mendo, A. (2014). La Teoría de la generalizabilidad aplicada al estudio del perfil físico durante juegos reducidos con diferente orientación del espacio en fútbol. International Journal of Sport Science, 10(37), 194-205. doi: http://dx.doi.org/10.5232/ricyde2014.03702

Casamichana, D., San Ramón-Quintana, J., Calleja-González, J., \& Castellano, J. (2013). Utilización de la limitación de contactos en el entrenamiento en fútbol: ¿afecta a las demandas físicas y fisiológicas?. International Journal of Sport Science, (9)33, 208221. doi: https://doi.org/10.5232/ricyde2013.03301

Casamichana, D., San Ramón-Quintana, J., Castellano, J., \& Calleja-González, J. (2012). Demandas físicas y fisiológicas en jugadores absolutos no profesionales durante partidos de fútbol 7: un estudio de caso. Cultura Ciencia Deporte, 7(20), 115-123. Retrieved from http://ccd.ucam.edu/index.php/revista/article/view/57

Castellano, J., Fernández, J., Castillo, A., \& Casamichana, D. (2010). Fiabilidad intraparticipante de diferentes modelos de dispositivos GPS implementados en un partido de Fútbol 7. Cultura Ciencia Deporte, 5(14), 85-95. Retrieved from http://ccd.ucam.edu/index.php/revista/article/view/97

Clemente, F., Santos, M., Lourenco, F., Ognyanova, M., \& Mendes, R. (2013). Activity Profiles of Soccer Players during The 2010 Word Cup. Journal of Human Kinetics, 38,201-211. Retrieved from http://www.johk.pl/files/johk-vol38-2013-21.pdf

Cohen, J. (1977). Statistical power analysis for the behavioral sciences. Retrieved from https://books.google.co.cr/books/about/Statistical power analysis for the behav.ht $\mathrm{ml}$ ?id=AG1qAAAAMAAJ\&redir esc $=y$

Daneshjoo, A., Halim, A., Rahnama, N., \& Yusof, A. (2013). The effects of injury prevention warm-up programmes oh knee strength in male soccer players. Biology of Sport, 30(4), 281-288. doi: https://doi.org/10.5604/20831862.1077554

Dellal, A., Owenc, A., Wong, D.P., Krustrup, P., Van Exsel, M., \& Mallo, J. (2012). Technical and physical demands of small vs. large sided games in relation to playing position in elite soccer. Human Movement Science, 31(4), 957-969. doi: https://doi.org/10.1016/j.humov.2011.08.013

Di Salvo, V., Baron, R., Tschan, H., Calderon, F.J., Bachl, N., \& Pigozzi, F. (2007). Performance characteristics according to playing position in elite soccer. International Journal of Sports Medicine, 28(3), 222-7. Retrieved from 
https://www.researchgate.net/publication/6769686 Performance Characteristics Ac cording to Playing Position in Elite Soccer

Febré, R., Chirosa, J., Casamichana, D., Chirosa, Martín-Tamayo, I., \& Pablos, C. (2015). Influencia de la densidad de jugadores sobre la frecuencia cardiaca y respuestas técnicas en jóvenes jugadores de fútbol. Revista Internacional de Ciencias del Deporte, 11(40). Retrieved from http://www.cafyd.com/REVISTA/ojs/index. php/ricyde/article/view/731

Gómez, A. J., Pallarés, J., Díaz, A., \& Bradley, P. (2013). Cuantificación de la carga física y psicológica en fútbol profesional: diferencias según el nivel competitivo y efectos sobre el resultado en competición oficial. Revista de Psicología del deporte, 22(2), 463-469. Retrieved from http://www.rpd-online.com/article/view/v22-n2-gomez-diazpallares-diaz-bradley

Gutiérrez-Vargas, R., Rojas-Valverde, D., Jiménez-Madrigal, E., Sánchez-Ureña, B., Salas-Naranjo, A., Gutiérrez-Vargas J.C., \& Salazar-Cruz, I. (2015). Parámetros Cinemáticos y Técnicos en Jugadores Jóvenes de fútbol Después de Modificar la Regla del Fuera de Juego (Regla 11). Kronos, 14(2). Retrieved from http://gse.com/es/entrenamiento-en-futbol/articulos/parametros-cinematicos-y-tecnicos-enjugadores-jovenes-de-futbol-despues-de-modificar-la-regla-del-fuera-de-juego-regla11-1905

Hill-Haas, S., Dawson, B., Impellizzeri, F., \& Coutts, A. (2011). Physiology of small sided games training in football. Sports Medicine, 41(3), 199-220. doi: https://doi.org/10.2165/11539740-000000000-00000

Hill-Haas, S., Rowsell, G., Dawson, B., \& Coutts, A. J. (2009). Acute physiological responses and time-motion characteristics of two small-sided training regimes in youth soccer players. The Journal of Strength \& Conditioning Research, 23(1), 111115. doi: https://doi.org/10.1519/JSC.0b013e31818efc1a

Johnston, R., Watsford, M., Kelly, S., Matthew, P., \& Spurrs, R. (2014). The validity and reliability of $10 \mathrm{~Hz}$ and $15 \mathrm{hz}$ GPs units for assessing athlete movement demands. Journal of Strength and Conditioning Research, 28(6), 1649-1655. doi: https://doi.org/10.1519/JSC.0000000000000323

Jones, S. \& Drust, B. (2007). Physiological and technical demands of 4 v 4 and 8 v 8 games in elite youth soccer player. Kinesiology, 39(2), 150-156. Retrieved from https://pdfs. semanticscholar.org/e85e/6700cb62c0b3630c8f8e52396cc33baf301b.pdf

Katis, A. \& Kellis, E. (2009). Effects of small-sided games on physical conditioning and performance in young soccer players. Journal of Sports Science and Medicine, 8(3), 374-380. Retrieved from http://www.jssm.org/researchissm-08-374.xml.xml

Kelly, D. \& Drust, B. (2009). The effect of pitch dimensions on heart rate responses and technical demands of small-sided soccer games in elite players. Journal of Science and Medicine in Sport, 12(4), 475-479. doi: https://doi.org/ $\underline{10.1016 / \text { i.jsams.2008.01.010 }}$ 
Kubo, K., Kanehisa, H., Ito, M., \& Fukunaha T. (2001). Effects of isometric training on the elasticity of human tendon structures in vivo. Journal of Applied Physiology, 91(1), 26-32. Retrieved from https://www.ncbi.nlm.nih.gov/pubmed/11408409

Moncada, J., Solera, A., \& Salazar, W. (2002). Fuentes de varianza e índices de varianza explicada en las ciencias del movimiento humano. Pensar en Movimiento: Revista de Ciencias del Ejercicio y la Salud, 2 (2), 70-74. doi: https://doi.org/ 10.15517/pensarmov.v2i2.398

Nevado-Garrosa, F. \& Suárez-Arrones, L. (2015). Comparación de las demandas físicas de tareas de fútbol reducido y la competición en jugadoras de fútbol sub 13. Cultura Ciencia Deporte, 10 (30); 235-243. Retrieved from http://ccd.ucam.edu/ index.php/revista/article/view/592

Rampinini, E., Impellizzeri, F., Castagna, C., Abt, G., Chamari, K., Sassi, A., \& Marcora, S. (2007). Factors influencing physiological responses to small-sided soccer games. Journal of Sports Sciences, 25(6), 659-666. doi: https://doi.org/10.1080/ $\underline{02640410600811858}$

Romero, A. \& Fernández, J. (2014). El entrenamiento interválico de alta intensidad (Tesis de Grado). Retrieved from http://dspace.umh.es/bitstream/11000/1911/1/\%C3\% 81ngel\%20Gabriel\%20Romero\%20Ant\%C3\%B3n.pdf

Safania, A., Alizadeh, R., \& Nourshahi, M. (2011). A Comparison of Small- Side Games and Interval Training on Same Selected Physical Fitness Factors in Amateur Soccer Players. Journal of Social Sciences, 7(3), 349-353. doi: https://doi.org/10.3844/issp.2011.349.353

Stolen, T., Chamari, K., Castagna, C., \& Wisloff, U. (2005). Physiology of Soccer. Sports of Medicine, 35(6), 501-536. doi: https://doi.org/10.2165/00007256-200535060$\underline{00004}$

Vargas, A., Urkiza, I., \& Gil, S. (2015). Efecto de los partidos de pretemporada en la planificación deportiva: Variabilidad en las sesiones de entrenamiento. Retos, 27, 45-51. Retrieved from https://recyt.fecyt.es/index.php/retos/article/view/34346

Contribution: A- Funding, B- Study design, C- Data collection, D- Statistical analysis and interpretation of results, E- Manuscript preparation. 